\title{
PREF ACE
}

This book is a sequel to my earlier Peking and the New Left (1969), which, however, discussed mainly Peking's own New Left, the Red Guards. The present volume examines Moscow's attitude toward the New Left outside the Soviet orbit. I am pleased to have both studies published by the University of California, the school I attended forty-seven years ago.

The New Left, in its by now classical form, had its heyday in the sixties, and came to an end toward the ebb of the American engagement in Vietnam. In this book, the term New Left encompasses all those revolutionary movements and groups in the West which desired to change the world and its life style radically, according to socialist principles but by methods and aims very different from those of the old left, led by Moscow. This New Left includes the rebellious Parisian students of May, 1968, the American and the German SDS (the initials are the same, the meanings somewhat different), the anarchists, Trotskyites, and Maoists (outside China), and the politically relevant groups among the hippies.

No systemization of the New Left's countless shifting trends and currents has been attempted here; Moscow too rarely differentiates among them. The reader can find an official Soviet interpretation of the New Left in the next-to-last document of this book. One thing is clear: leftists who do not fit into current Soviet tactics are denigrated by the Soviet leadership, and called "leftists" in quotation marks. Only unswerving followers of the Moscow line may call themselves plain leftists. My practice, on the contrary, is to use quotation marks only when quoting from Soviet sources. For me the New Left is left.

What, then, is the New Left for the Soviet leaders-an ally, rival, or an enemy? What is their attitude toward radical movements on the left which adamantly refuse Moscow's dogma $t$ ' at socialism, by definition, can only be Soviet socialism, as interpreted and practiced by the USSR? Is it irrelevant for the "socialist Soviet Union" what happens ideologically in the "capitalist West," is the Soviet Union immune to movements in West- 
ern industrial society, among them the unrest of youth, or do such movements manage to penetrate the thought curtain along the Soviet border?

To seek answers to these questions seemed valuable, for they could show, applied to an interesting model, the New Left, how Moscow reacts to unexpected events abroad, and whether its thinking has managed to mature beyond simplistic, black-and-white propaganda toward greater sophistication. The answers to these questions might also indicate whether Soviet readers, from their publications, learn more than clichés about intellectual developments outside their country, and perhaps even whether such information, through a kind of osmosis, can exert an influence on them.

Apart from conversations with Soviet citizens, Soviet publications are the chief basis of this study. In addition to all books and pamphlets avail. able, I used primarily twenty-five Moscow periodicals (generally for the five years from 1968 on, in some instances beginning with 1960). Thus I found some four hundred relevant articles, which, together with the books and pamphlets, add up to about 3,000 magazine pages. Articles in the daily press are not included in these figures; these were investigated only for periods of unusual tension, like May and June 1968 during the Paris uprising.

For the Western reader and researcher it is awkward that, with few exceptions, Soviet writers have not yet learned to cite chapter and verse for their quotations. They refer to books used without indicating where and when these were published, they cite authors as witnesses without giving their initials, when referring to articles they seldom mention the year of publication, let alone the exact date. Indexes are rare.

This book, by giving detailed bibliographical data, tries to enable the reader to check all the material employed. Where only one article by an author was used, only his name is given in parenthesis (e.g. Afanas'yev); if more than one article, the key word of each title is added (e.g. Kon, "Reflections"). One short chapter ("Materials") discusses the periodicals examined, another ("Authors") tells the reader about the most important writers cited. Excerpts from twenty-five articles are printed as documents in the appendix, along with some relevant quotations from Lenin and from official statements.

Most of the book was written from September 1972 to June 1973, while I was the guest of Columbia University's Research Institute on Communist Affairs. My sincere thanks to my host Zbigniew Brzezinski, the Institute's director, and his staff and my colleagues, especially Marshall and Colette Shulman, and students in New York for their stimulating ideas and fellowship during many informative discussions. My thanks, also, to 
the staff of Columbia's Russian Institute, Library of the School of International Affairs, and Butler Library.

My thanks to Max Knight of the University of California Press for his great help, and my appreciation for the work of the translators, Helmut Fischer (from the German text) and Luther Wilson (from the Russian). Mr. Wilson has followed the transliteration system of the United States Board on Geographic Names, with the modification that names ending in $i y$ are rendered with a plain $y$. Ellipses in Russian originals are given as dots ...., omissions by the author as [...].

In the present book the author participates as a third party in the debate between Moscow and the New Left. Knowing both parties and their dialogue from the beginning, though aligned with neither side, I am concerned with their future and that of the world in general. Thus I hope that this book-my share, so to speak, in a three-way dialogue-may contribute to a new, emerging style of debate suitable to our age, an age of peaceful coexistence, yet one in which (as the Soviet leaders tell us unceasingly) the "ideological struggle" cannot be dispensed with.

The echo from Moscow to the German edition, to be sure, has not been especially encouraging. E. Ambartsumov, three of whose articles are mentioned in this book, published an ill-tempered review of more than 3,000 words in Literaturnaya Gazeta $(6,1974,14)$. Among his dislikes is my chapter on Lenin. The Moscow dogmatists, I realize, prefer a monopoly on interpreting Lenin, but like it or not, they must grant to foreign observers the right to check the words of the master before examining the writings of his lesser disciples. If Ambartsumov found factual errors, he does not disclose them, nor does he contribute any pertinent statements by Lenin which I might have overlooked.

On the one hand, Ambartsumov detects contradictions between the book's assertion that Moscow for many years had overlooked the New Left and, on the other hand, my repeated reference to statements by Soviet writers who did in fact discuss the New Left. It is easy, of course, for Soviet authors to criticize a foreign book because no reader of their reviews will ever read the book. (None of the fifteen copies of the German edition which I sent to friends in Moscow reached them.) Hence readers of Ambartsumov will never know that what he calls a contradiction is merely the result of lapse of time: Until 1968 the New Left was indeed overlooked, after the Paris revolt of that year it was noted and gradually understood. Is it a contradiction if, in reporting a process, its first phase is seen to differ from the second, as the egg differs from the chicken? 
Any favorable remarks which I make about Soviet authors (and there are quite a few) do not fit into the Soviet picture of the biased Western observer; each time, therefore, Ambartsumov jubilantly declares that 1 was "forced to admit" this or that. Forced by whom, Mr. Ambartsumov? Even now it is inconceivable to him and some of his colleagues that as a rule Western scholars study problems to discover the facts, not to prove a point.

According to Ambartsumov, I am constitutionally incapable of grasping Soviet realities because my German grandfather once owned a chocolate factory in Moscow. To say that my grandfather, who died in 1907, and his factory (incidentally still the best in the USSR, under the new name Red October) have determined my Weltanschauung, approaches the worst kind of primitive Marxism. But if grandfathers are indeed important, what about a study concerning the grandfathers of current Moscow ideologues? How many such grandfathers were red-blooded proletarians? Surely Ambartsumov's were not.

The attack against the book shows how unhappy Moscow is about the New Left's peculiar ways, and about foreign authors describing Moscow's slowness of reaction to it. Obviously Ambartsumov, originally not a bad writer, after some troubles during recent years hopes to ingratiate himself with his superiors by his review. I wish him well. But he did not proceed very skillfully:

He thought it witty to compare me with Gulliver's Laputians, one of whose "Eyes turned inward, and the other directly up to the Zenith." Very well. But he forgot that the inhabitants of Laputa also have other characteristics: Their clothes are, as Jonathan Swift tells us, "very ill made, and quite out of Shape," their "Houses are very ill built, the Walls bevil," "They long to see the world" although permission "is not easy to be obtained," and they even demand "great Immunitys, the Choice of their own Governor, and other like Exorbitances," for which, of course, they are severely punished. These and many other Laputian features resemble conditions less in the West than in a country much closer to Mr. Ambartsumov, and much more familiar to him.

It might have been wiser for him not to quote the fancies of Jonathan Swift, but to stick to verifiable facts, as we shall now proceed to do.

Berkeley (California) and 